\title{
PENGATURAN DAN RUANG LINGKUP CONTEMPT OF COURT DI INDONESIA
}

\section{Syarif Nurhidayat}

Fakultas Hukum Universitas Islam Indonesia, Yogjakarta syarif.nurhidayat@uii.ac.id

\begin{abstract}
Abstrak
Penelitian ini bertujuan memetakan kembali pengaturan dan ruang lingkup Contempt of Court $(\mathrm{CoC})$ di Indonesia. $\mathrm{CoC}$ adalah istilah yang belum memiliki istilah yang sama persis dalam bahasa Indonesia. CoC sering disebut sebagai tindakan merendahkan otoritas atau keadilan. CoC lebih dipahami sebagai kejahatan, meskipun cakupannya harus lebih luas dari sekedar kejahatan. Ini membuatnya menarik dan penting untuk memetakan pengaturan perbuatan yang masuk kategori $\mathrm{CoC}$ dan pada saat yang sama memetakan ruang lingkup nya secara komprehensif. Penelitian ini merupakan penelitian normatif dengan pendekatan perundang-undangan dan konseptual. Berdasarkan hasil penelitian, setidaknya ada tiga peraturan yang mengatur tindakan $\mathrm{CoC}$, yaitu Undang-Undang Hukum Pidana, Peraturan Mahkamah Agung, Hukum Pidana di luar KUHP, perturan persidangan, dan Kode Perilaku Hakim. Sebagai konsekuensi dari berbagai peraturan yang mengatur, ruang lingkup tindakan $\mathrm{CoC}$ dapat dipetakan menjadi tindakan di bidang etika, peraturan ketertiban, administrasi, dan pidana. Studi ini bermaksud memberikan gambaran besar tentang $\mathrm{CoC}$ sehingga diharapkan dapat menjadi acuan kebijakan penyusunan peraturan maupun penegakan hukum.
\end{abstract}

Kata kunci: Contempt Of Court; Pengaturan; Ruang Lingkup. 


\title{
REGULATION AND SCOPE OF THE CONTEMPT OF COURT IN INDONESIA
}

\begin{abstract}
This study aims to remap the regulation and scope of the Contempt of Court (CoC) in Indone sia. CoC is a term that does not yet have the exact same term in bahasa. CoC is often referred to as an act of degrading authority or justice. CoC is better understood as a crime, although its scope must be broader than just crime. This makes it interesting and important to map out the arrangements for actions that fall into the category of $\mathrm{CoC}$ and at the same time map the scope comprehensively. This research is a normative research with a statutory and conceptual approach. Based on the results of the study, there are at least three regulations governing CoC actions, namely the Criminal Law Act, Supreme Court Regulations, Criminal Law outside the Criminal Code, trial rules, and the Code of Judges' Behavior. As a consequence of the various regulations that govern, the scope of CoC actions can be mapped into actions in the fields of ethics, order, administration, and criminal law. This study intends to provide a big picture of $\mathrm{CoC}$ so that it is expected to be a reference policy for the preparation of regulations and law enforcement.
\end{abstract}

Keywords: Contempt Of Court; Regulation; Scope.

\section{PENDAHULUAN}

\section{A. Latar Belakang}

Contempt of court (CoC) merupakan istilah yang belum memiliki padanan istilah dalam bahasa indonesia secara pasti. CoC sering disebuat sebagai perbuatan merendahan kewibawaan atau martabat peradilan. Ada juga yang menyebutnya dengan perbuatan menentang kekuasaan kehakiman. ${ }^{1}$ Istilah contempt of court dapat ditemukan pada penjelasan umum butir ke empat alinea ke empat Undang-Undang Nomor 14 ttahun 1985 tentang Mahkamah Agung yang menyebutkan "bahwa selanjutnya untuk dapat lebih menjamin terciptanya suasana yang sebaik-baiknya bagi

\footnotetext{
${ }^{1}$ Sutanto Nugroho dkk., "Pengaturan Tindak Pidana Contempt of Court Berdasarkan Sistem Hukum Pidana Indonesia”, Diponegoro Law Journal 6 (2), 2017, hal 9.
} 
penyelenggaraan peradilan guna menegakkan hukum dan keadilan yang mengatur penindakan terhadap perbuatan, tingkah laku, sikap dan/atau ucapan yang dapat merendahkan dan merongrong kewibawaan, martabat, dan kehormatan badan peradilan yang dikenal sebagai contempt of court”.

Bentuk perbuatan dari CoC sendiri sampai saat ini masih belum bersifat pasti. Belum lama ini, Komisi Yudisial melakukan survei persepsi secara tertutup kepada para hakim di tingkap pertama, mengenai perbuatan apa saja yang bisa disebut atau dikategorikan sebagai CoC. Hasilnya meski masih sementara sudah diterbitkan secara terbatas dalam kelas Training of Trainer Klinik Etik dan Hukum di Bogor, sebagai berikut: ${ }^{2}$

1. Membuat onar atau gaduh di pengadilan (misbehaving in court).

2. Mengalangi atau mengabaikan putusan BHT (Berkekuatan Hukum Tetap) (disobeying court order).

3. Demonstrasi yang mengganggu proses persidangan (obstracting justice).

4. Terror/ ancaman/ intimidasi (obstracting justice).

5. Pencemaran nama baik hakim atau pengadilan (Scandalising Court).

6. Kekerasan fisik terhadap Hakim (obstracting justice).

7. Perusakan sarana dan prasarana pengadilan (misbehaving in court).

8. Komentar berlebih terhadap proses pengadilan maupun putusan yang belum BHT (subjudice rule). ${ }^{3}$

Selain perbuatan di atas, ada juga perbuatan yang dapat dikategorikan sebagai CoC yang masuk dalam ranah pidana, seperti diatur dalam Pasal 218, 217, 316, 216, 221, 223, 224, 207, 212, 214 KUHP.

${ }^{2}$ Bahan pelatihan ToT Program Klinik Etik dan Hukum, yang diselen ggarakan oleh Komisi Yudisial pada tanggal 12-15 Maret 2018, di Bandung.

${ }^{3}$ Bentuk-bentuk perbuatan ini, senada dengan temuan penelitian yang dilakukan oleh Amirudin, dia meny impulkan "ada empat perbuatan pidana y ang kerap terjadi: Perilaku tercela dan tidak pantas di peradilan; tidak mentaati perintah pengadilan, menyerang integritas dan imparsialitas pengadilan; men ghalangi jalannya penyelenggaraan peradilan". Lihat, Amirudin, "Delik Penghinaan Terhadap Pengadilan (Contempt of Court) dalam Perkara Pidana di Indonesia”, Jurnal Penelitian Hukum Legalitas 9 (2), 2016, hal 83.

DOI: $10.31479 /$ jphl.v9i2.107 
Perbedaan pemahaan dan tidak adanya keseragaman terjadi bisa jadi dikarenakan tidak adanya norma peraturan yang jelas mengenai $\mathrm{CoC}$ ini. Perbedaan perspektif semakin meruncing ketika norma yang mengatur tidak bersifat pasti. Hal ini juga berakibat pada sikap ragu-ragu hakim dalam melakukan implementasi hukum terhadap pelaku CoC. ${ }^{4}$

Selain kondisi objektif di atas yang menunjukkan ragam pendapat tentang $\mathrm{CoC}$, ada beberapa pertimbangan mendasar, mengapa pengaturan CoC eksis dan perlu diperkuat. Beberapa alasan tersebut antara lain:

1. Fenomena distrust masyarakat pada lembaga pengadilan yang tidak berkualitas.

2. Pengadilan sebagai tempat mengadukan, memperjuangkan dan mendapatkan keadilan

3. Keputusan pengadilan bersifat mengikat

4. Menjaga imparsialitas/ tidak memihak lembaga pengadilan. ${ }^{5}$

Beberapa kajian sebelumnya yang mengkaji tentang $\mathrm{CoC}$ lebih banyak mengkaji CoC sebagai sebuah tindak pidana semata. Misalnya, penelitian yang dilakukan oleh Rhivent Marchel Michael Samatara (2017) dengan judul "Tindak Pidana Terhadap Lembaga Peradilan (Contempt Of Court) Menurut Hukum Positif Indonesia". 6 Penelitian ini fokus membahas CoC dalam konteks hukum pidana yang ditujukan kepada lembaga peradilan, bukan sebagai sistem. Kemudian, Sutanto Nugroho (2017) juga melakukan penelitian dengan judul "Pengaturan Tindak Pidana Contempt of

\footnotetext{
${ }^{4}$ Ruby Hadiarti Johny, “Contempt Of Court (Kajian tentang Ide Dasar dan Implementasinya dalam Hukum Pidana)”, Jurnal Dinamika Hukum 9 (2), 2009, hal 143. DOI: $\underline{10.20884 / 1 . j d h .2009 .9 .2 .221}$

${ }^{5}$ Pengaturan secara lebih sistematis dan kuat tentang Contempt of Court sebagai "sebuah pranata hukum pada sistem peradilan di Indonesia dipandang sebagai kebutuhan objektif. Hal ini dikarenakan makin banyaknya praktek perendahan martabat peradilan dalam berbagai bentuk perbuatan”. Lihat, Puslitbang Hukum dan Peradilan Mahkamah Agung, Naskah Akademik Contempt Of Court 2002, www.ma.go.id. hal 72.

6 Rhivent Marchel Michael Samatara, "Tindak Pidana Terhadap Lembaga Peradilan (Contempt of Court) Menurut Hukum Positif Indonesia”, Lex Privatum 5 (9), 2017. DOI: https://ejournal.unsrat.ac.id/index.php/lexprivatum/article/view/18351
} 
court Berdasarkan Sistem Hukum Pidana Indonesia". 7 penelitian tersebut fokus mengkaji pengaturan $\mathrm{CoC}$ sebagai sebuah tindak pidana. Sementara, Amiruddin (2016) fokus mengkaji salah satu bentuk CoC dalam konteks pidana juga, yaitu dalam penelitiannya yang berjudul "Delik Penghinaan Terhadap Pengadilan (Contempt of Court) dalam Perkara Pidana di Indonesia". 8 Terakhir, kajian yang dilakukan oleh Artaji (2018) dengan judul "Eksistensi Pranata Contempt of Court dalam Peradilan di Indonesia". 9 Penelitian ini memberikan gambaran bagaimana $\mathrm{CoC}$ terjadi dan diselesaikan melalui sistem peradilan pidana.

Berdasarkan pemaparan beberapa kajian di atas, CoC banyak dikaji dan dipersepsikan dalam kerangka tindak pidana. Padahal, jika $\mathrm{CoC}$ adalah semua perbuatan yang bersifat dan mengakibatkan penghinaan dan perendahan terhadap peradilan, maka mestinya ruang lingkup CoC lebih luas daripada sekedar tindak pidana. Oleh karena itu, kajian ruang lingkup $\mathrm{CoC}$ ini menjadi penting agar tampak jangkauan $\mathrm{CoC}$ bukan hanya sekedar tindak pidana saja. Hasil penelitian ini diharapkan menjadi pelengkap bahan kajian tentang $\mathrm{CoC}$ dan dapat menjadi salah satu bahan pertimbangan dalam pengambilan kebijakan regulasi. Mampu memberikan perspektif kepada publik, bahwa $\mathrm{CoC}$ bisa jadi terjadi dari ruang dalam aktor dan sistem peradilan itu sendiri. Penelitian ini bertujuan memetakan kembali pengaturan dan ruang lingkup contempt of court $(\mathrm{CoC})$ di Indonesia. $\mathrm{CoC}$ adalah istilah yang belum memiliki istilah yang sama persis dalam bahasa Indonesia. CoC sering disebut sebagai tindakan merendahkan otoritas atau keadilan.

\section{B. Perumusan Masalah}

${ }^{7}$ Sutanto Nugroho dkk, "Pengaturan Tindak Pidana Contempt Of Court Berdasarkan Sistem Hukum Pidana Indonesia”, Diponegoro Law Journal 6 (2), 2017, hal 9.

${ }^{8}$ Amiruddin, Op.Cit. hal 83.

9 Artaji dkk, "Eksistensi Pranata Contempt of Court dalam Peradilan di Indonesia”, Jurnal Pengabdian Kepada Masyarakat 2 (8), 2018, hal 676. DOI: http://jurnal.unpad.ac.id/pkm/article/view/20309 
Berdasarkan pemaparan masalah di atas, maka penting untuk diketahui konsep pengaturan $\mathrm{CoC}$ di Indonesia saat ini, sehingga bisa dipetakan dengan pasti ruang lingkup tindakan yang dapat dikategorikan sebagai CoC.

\section{Metode Penelitian}

Penelitian ini adalah penelitian yuridis normatif. ${ }^{10}$ Penelitian ini dengan kajian hukum berdasarkan norma yang sudah berlaku dan berada dalam peraturan yang berlaku. Penelitian ini menggunakan pendekatan perundang-undangan dan pendekatan konseptual. Pendekatan perundang-undangan digunakan untuk melakukan analisis dan identifikasi normatif terkait contempt of court dalam peraturan yang ada. Sementara pendekatan konseptual digunakan untuk menganalisa peta peraturan sebagai bagian dari sistem hukum dan memetakan ruang lingkup dari contempt of court sehingga dengan mudah dipahami sebagai sebuah konsep yang jelas.

Penelitian ini menggunakan studi pustaka ${ }^{11}$ sebagai metode pengumpulan data sekunder penelitian berupa bahan hukum. ${ }^{12}$ Teknik ini dilakukan dengan mengumpulkan peraturan, naskah, buku atau hasil kajian

10 Bernard Arief Sidharta, "Penelitian Hukum Normatif: Analisis Penelitian Filosofikal dan Dogmatikal", dalam Sulistyowati Irianto \& Shidarta (ed), "Metode Penelitian Hukum; Konstalasi dan Refleksi”, Yayasan Obor Indonesia, 2009, Jakarta, hal 142-149.

11 "Pemilihan teknik pengumpulan data bergantung pada ruang lingkup dan tujuan dari penelitian itu sendiri. Paling tidak ada tiga cara pengumpulan data, yaitu studi dokumen atau pustaka, pengamatan atau observasi, dan wawancara atau interview. Ketiga teknik tersebut, dapat digunakan salah satu atau digabung ketiganya sekaligus". Lih at Soerjono Soekanto, "Pengantar Penelitian Hukum", Cet. 3, Penerbit Universitas Indonesia, 2012, Jakarta, hal 66.

12 "Bahan hukum primer adalah semua aturan hukum yang dibentuk dan/atau dibuat secara resmi oleh suatu lembaga negara, dan/atau badan-badan pemerintahan, yang demi tegaknya akan diupayakan berdasarkan daya paksa yang dilakukan secara resmi pula oleh aparat negara". "Bahan hukum sekunder adalah bahan hukum yang berfungsi sebagai sumber hukum materiil yaitu semua informasi yang relevan dengan permasalahan hukum, namun tidak dapat dibilangkan sebagai aturan-aturan hukum yang pernah diundangkan atau diumumkan sebagai produk badan-badan legislative, yudisial, eksekutif, dan/atau administrasi negara". "Bahan hukum tertier adalah bahan-bahan yang termuat dalam kamus-kamus hukum, berbagai terbitan yang memuat indeks hukum, dan semacamnya. Ia berfungsi sebatas sebagai informasi referensi, sebagai entri, alias pintu masuk, untuk membukakan akses bagi peneliti yang hendak memasuki sumber-sumber hukum sebenarnya, baik formil maupun materiil". Lihat, Soetandyo Wignyosoebroto, “Hukum Konsep dan Metode”, Setara Press, 2013, Malang, hal 81-85. 
terkait dengan tema contempt of court, kemudian menganalisis untuk kemudian disajikan dan disimpulkan. Pada penelitian normatif, pengolahan atau analisis data pada hakekatnya adalah mengadakan sistematisasi terhadap bahan-bahan hukum tertulis. Sistematisasi berarti membuat klasifikasi terhadap bahan-bahan tertulis tersebut, untuk memudahkan pekerjaan analisa dan konstruksi. ${ }^{13}$

Analisis data yang digunakan dalam penelitian ini adalah deskriptif kualitatif, ${ }^{14}$ yaitu "data yang diperoleh disajikan secara deskriptif dan dianalisis secara kualitatif (content analysis) dengan langkah menganalisis dan menyajikan fakta secara sistematik sehingga dapat lebih mudah untuk difahami dan kemudian disimpulkan. Kesimpulan yang diberikan selalu jelas dasar faktualnya sehingga semuanya selalu dapat dikembalikan langsung pada data yang diperoleh". ${ }^{15}$

\section{PEMBAHASAN}

\section{A. Konsep dan Sejarah Contempt of Court di Indonesia}

Secara etimologis, contempt of court terdiri atas dua kata, yakni contempt dan court. Contempt diartikan sebagai melanggar, menghina, memandang rendah. Kata court diartikan sebagai pengadilan. Dari pengertian tersebut secara singkat contempt of court dapat dimaknai sebagai upaya untuk melanggar, menghina, memandang rendah pengadilan. ${ }^{16}$

Kata contempt dalam bahasa Inggris mengandung 5 arti:

1. Lack of respect accompanied by a feeling of intense dislike. (noun, feeling);

13 Ibid., hal 251.

${ }^{14}$ Ini merupakan konsekuensi dari pilihan penggunaan data sekunder, maka lazimnya analisa dan konstruksi datany a dilakukan secara kualitatif. Peny ajian data dan analisis data kualitatif dilakukan sekaligus. Lihat, Ibid., hal 69.

15 Saifuddin Azwar, “Metode Penelitian”, Ctk. Kedua, Pustaka Pelajar, 1999, Yogy akarta, hal 6.

${ }^{16}$ Lilik Mulyadi dan Budi Suhary anto, "Contempt of Court di Indonesia”, Alumni, 2016, Bandung, hal 77. 
2. A manner that is generally disrespectul and contemptous. (noun, attribute);

3. Open disrespect for a person or thing. (noun, communication);

4. A wilful disobedience to or disrespect for the authority of a court or legislative body (non, act);

5. The act of connecting or despising; the feeling with which one regards that which is esteemed mean, vile, or worthless, disdain, scorn (noun). ${ }^{17}$

Sementara Black memberikan makna pada Contempt of Court sebagai berikut:

"any act which is calculated to embarrass, hinder, or obstruct court in administration of justice, or which is calculated to lessen its authority or dignity. Commited bay e person who does any act in willful contravention of its authority or dignity, or tending to impede or frustrate the administration of justice, or by one who, being under the court's authority as a partyto a proceeding therein, willfully disobeys its lawful orders or fails to comply with an undertaking which he has given.",18

Lilik dan Budi secara konseptual berusaha memberikan batasan pengertian contempt of court yaitu "tindak pidana yang dapat dilakukan oleh orang yang terlibat dalam suatu proses perkara maupun tidak, di dalam maupun di luar pengadilan, dilakukan perbuatan secara aktif maupun pasif, merendahkan kewibawaan dan martabat pengadilan atau menghalangi pejabat pengadilan di dalam menjalankan pengadilan". ${ }^{19}$

Dalam literatur common law, criminal contempt secara singkat sering disebut sebagai "offences against the administration of justice". Barda Nawawi Arief mengklasifikasikan bentuk-bentuk atau ruang lingkup criminal contempt sebagai berikut: ${ }^{20}$

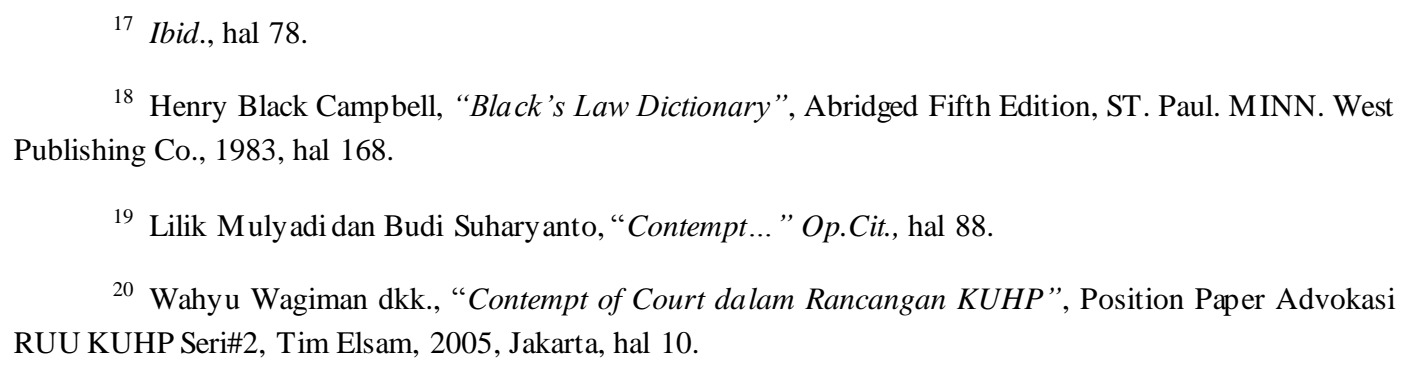

${ }^{20}$ Wahy u Wagiman dkk., "Contempt of Court dalam Rancangan KUHP”, Position Paper Advokasi RUU KUHP Seri\#2, Tim Elsam, 2005, Jakarta, hal 10. 
1. Gangguan di muka atau di dalam ruang sidang pengadilan;

2. Perbuatan-perbuatan untuk mempengaruhi proses peradilan yang tidak memihak;

3. Perbuatan yang memalukan atau menimbulkan skandal bagi pengadilan;

4. Mengganggu pejabat pengadilan;

5. Pembalasan terhadap perbuatan-perbuatan yang dilakukan selama proses peradilan berjalan;

6. Pelanggaran kewajiban oleh pejabat pengadilan;

7. Pelanggaran oleh pengacara.

Kasus contempt of court pertama kali muncul di Indonesia terjadi pada saat persidangan H.R. Dharsono anggota Petisi 50 dengan advokatnya Adnan Buyung

Nasution. Adnan Buyung Nasution dinyatakan telah melakukan contempt of court oleh Ketua Pengadilan Negeri Jakarta Pusat, karena advokat tersebut dianggap menghina pengadilan dengan aksi protesnya ketika mengadakan pembelaan dalam perkara H.R Dharsono atas dakwaan melakukan tindak pidana subversi. Adnan Buyung Nasution dianggap membuat keributan di pengadilan yang mengakibatkan advokat itu mendapat teguran, bahkan pada proses selanjutnya Dewan Kehormatan IKADIN telah menyatakan perbuatan advokat itu telah melanggar kode etik advokat. Tindakan itu ditindaklanjuti dengan dikeluarkannya Surat Keputusan Menteri Kehakiman RI yang menghentikan acara profesinya selama 1 (satu) tahun. ${ }^{21}$

Pengaturan contempt of court secara eksplisit pertama kali di Indonesia dapat ditemukan dalam penjelasan umum UU No. 14 Tahun 1985 tentang Mahkamah Agung butir 4 alinea ke-4 yang berbunyi:

"Selanjutnya untuk dapat lebih menjamin terciptanya suasana yang sebaik-baiknya bagi penyelenggaraan peradilan guna menegakkan hukum dan keadilan berdasarkan Pancasila, maka perlu pula dibuat

\footnotetext{
${ }^{21}$ Artaji dkk, Op. Cit., hal 676.
} 
suatu undang-undang yang mengatur penindakan terhadap perbuatan, tingkah laku, sikap dan/atau ucapan yang dapat merendahkan dan merongrong kewibawaan, martabat, dan kehormatan badan peradilan yang dikenal sebagai contempt of court"'.

Berdasarkan ketentuan di atas, tampak bahwa ada kesadaran untuk membuat sebuah norma khusus berupa undang-undang yang akan mengatur tentang perbuatan yang disebut sebagai contempt of court. Dalam penjelasan tersebut, tidak disebutkan jenis perbuatan tersebut apakah berupa perbuatan pidana ataukah bukan. Pada prinsipnya, perlu diatur mengenai segala perbuatan, tingkah laku, sikap dan/atau ucapan yang dapat merendahkan dan merongrong kewibawaan, martabat dan kehormatan badan peradilan.

Peradilan di dalamnya mengandung makna bukan saja institusi pengadilan sebagai lembaga, namun juga kehormatan dan marwah aparat penegak hukum yang menyelenggarakan sistem peradilan itu sendiri yang meliputi proses pemeriksaan saksi-saksi, pemeriksaan terdakwa, dan pemeriksaan barang bukti. ${ }^{22}$ Dilihat dari konteks peradilan pidana, Barda Nawawi Arief secara eksplisit menyatakan 'bahwa sistem peradilan pidana identik dengan sistem kekuasaan kehakiman di bidang hukum pidana yang diimplementasikan dalam empat subsistem, yaitu (1) kekuasaan penyidikan oleh lembaga penyidik; (2) kekuasaan penuntutan oleh lembaga penuntut umum; (3) kekuasaan mengadili/menjatuhkan putusan oleh badan peradilan; dan (4) kekuasaan pelaksanaan hukum pidana oleh aparat pelaksana eksekusi". 23

Dengan memahami bahwa peradilan adalah sebuah sistem yang termasuk di dalamnya organ yang menjalankan sistem, maka menjaga marwah peradilan berarti pula menjaga marwah dan kehormatan para penegak hukum dan ogrnaisasinya meliputi kepolisian, kejaksaan dan

${ }^{22}$ Oly Viana Agustine, "Sistem Peradilan Pidana: Suatu Pembaharuan”, Rajawali Pers, 2019, Depok, hal 119.

${ }^{23}$ Ibid., hal 5. 
kehakiman, baik polisi, jaksa, maupun hakim, termasuk juga kehormatan tenaga penyelenggara sistem peradilan.

Hingga saat ini, belum ada perundang-undangan khusus yang mengatur tentang contempt of court sebagaimana diamanahkan oleh UU Mahkamah Agung. Namun begitu, di beberapa bentuk norma, dapat diidentifikasi sebagai aturan yang mengatur tentang perilaku, perbuatan, sikap dan/atau ucapan yang merendahkan peradilan. Mulai dari aturan norma etika perilaku, tata tertib, administrasi, hingga norma pidana.

Bagi semua profesi hukum sebagai bagian dari pelaksana sistem peradilan, semuanya telah memiliki kode etik profesi masing-masing, mulai dari kode etik kepolisian, advokat, jaksa, hingga kode etik dan perilaku hakim. Kode etik disusun dalam rangka (1) sebagai alat untuk membina dan pembentukan karakter serta pengawasan dari penegak hukum; (2) sebagai sarana kontrol sosial, dimana masyarakat dapat turut melakukan kontrol terhadap perilaku penegak hukum dan mencegah adanya campur tangan ekstra yudisial; (3) sebagai jaminan bagi peningkatan moralitas hakim dan kemandirian fungsional bagi hakim; dan (4) untuk menumbuhkan kepercayaan masyarakat pada lembaga penegak hukum. ${ }^{24}$

Semua penegak hukum terikat pada kode etik profesi masing-masing. Pelanggaran atas kode etik secara otomatis menjadikan masyarakat tidak percaya dan memandang rendah hasil proses peradilan. Misalnya, ketika hakim dipandang tidak profesional dalam mengadili sebuah kasus, maka putusan yang dihasilkan tidak akan diindahkan oleh masyarakat. Banyaknya pelanggaran etika, menjadikan marwah lembaga dan legitimasi proses menjadi jatuh. Dengan demikian, pada dasarnya kode etik adalah norma yang selain menjaga marwah personal, juga marwah proses dan kelembagaan peradilan. Hal ini bias diartikan bahwa kode etik adalah

\footnotetext{
${ }^{24}$ Wildan Suyuthi Mustofa, “Kode Etik Hakim”, Edisi Kedua, Kencana, 2013, Jakarta, hal 127-128.
} 
bagian dari norma contempt of court yang dimaksudkan dalam UU Mahkamah Agung di atas.

Selain diatur dalam kontek kode etik profesi penegak hukum, aturan contempt of court juga dapat ditemukan dalam aturan norma tata tertib persidangan dalam rangka memberikan penghormatan dan menjaga marwah peradilan. Misal di Pengadilan Negeri Sleman, diatur sedemikian rupa terkait tata tertib sidang. Beberapa pasal dalam KUHP dapat diidentifikasi pengaturan perbuatan yang dapat dikategorikan sebagai contempt of court, yaitu antara lain dan tidak terbatas pada Pasal 207, Pasal 217, juga Pasal 224.

Berdasarkan kajian di atas, pada dasarnya pengertian contempt of court dapat diartikan dalam konsep yang luas dan konsep yang sempit. Dalam konsep luas, contempt of court meliputi semua perbuatan yang bersifat melecehkan dan merendahkan martabat peradilan maupun aktor penyelenggara peradilan, baik di dalam maupun di luar peradilan. Sementara pengertian contempt of court yang lebih sempit, lebih sering dipahami dalam konteks criminal contempt of court, yakni tindak pidana berupa merendahkan dan/atau melecehkan martabat peradilan maupun aktor penyelenggara peradilan baik di dalam ruang persidangan maupun di luar.

Secara garis besar dapat dinyatakan bahwa contempt of court di Indonesia diatur dalam berbagai bidang peraturan. Ada yang diatur dalam bentuk peraturan tata tertib, ada juga yang sudah diatur dalam norma undang-undang pidana. Namun begitu, istilah contempt of court lebih dikenal dalam kalangan sarjana hukum pidana, sehingga begitu disebutkan contempt of court, selalu yang dibahas adalah criminal contempt of court.

\section{B. Pengaturan Contempt of Court di Indonesia}

Ada berbagai peraturan yang ada di Indonesia, yang memuat di dalamnya larangan atau konten terkait larangan contempt of court sebagai berikut.

\section{Undang-Undang Nomor 14 tahun 1985 tentang Mahkamah Agung}


Penelusuran istilah contempt of court dalam peraturan perundangan di Indonesia, pertama kali disebut dalam Undang-undang Nomor 14 tahun 1985 tentang Mahkamah Agung. Namun dalam UU Kehakiman ini belum diatur mengenai norma tentang contempt of court, melainkan hanya mengamanahkan saja perlunya dibuat peraturan khusus mengenai contempt of court. Pada penjelasan umum UU Kehakiman ini, pada angka 4 secara eksplisit disebutkan:

"Untuk memperoleh hakim agung yang merdeka, berani mengambil keputusan dan bebas dari pengaruh, baik dari dalam maupun dari luar, diperlukan persyaratan sebagaimana diuraikan dalam Undang-undang ini. Pada dasarnya pengangkatan hakim agung berdasarkan sistem karier dan tertutup.

Namun demikian dalam hal-hal tertentu dapat pula dibuka kemungkinan untuk mengangkat Hakim Agung yang tidak didasarkan sistem karier. Untuk hakim agung yang didasarkan sistem karier berlaku ketentuan Pasal 11 Undang-undang Nomor 8 Tahun 1974 (Lembaran Negara Tahun 1974 Nomor 55, Tambahan Lembaran Negara Nomor 3041). Selanjutnya untuk dapat lebih menjamin terciptanya suasana yang sebaik-baiknya bagi penyelenggaraan peradilan guna menegakkan hukum dan keadilan berdasarkan Pancasila, maka perlu pula dibuat suatu undang-undang yang mengatur penindakan terhadap perbuatan, tingkah laku, sikap dan/atau ucapan yang dapat merendahkan dan merongrong kewibawaan, martabat, dan kehormatan badan peradilan yang dikenal sebagai " contempt of court " 25

Pada UU Kehakiman di atas, ada filosofi yang dibangun bahwa kepentingan menyusun undang-undang yang mengatur tentang contempt of court yaitu dalam rangka menjamin terciptanya suasana yang sebaik-baiknya bagi penyelenggaraan peradilan guna menegakkan hukum dan keadilan berdasarkan Pancasila. Selain itu, bentuk aturan yang dimaksudkan adalah aturan tentang penindakan. Secara eksplisit tidak disebutkan apakah undang-undang yang dimaksud adalah undang-undang pidana, ataukah undang-undang administrasi. Sementara perbuatan yang dimaksud untuk

\footnotetext{
${ }^{25}$ Penjelasan umum angka 4, UU No. 14 tahun 1985 tentang Mahkamah Agung.
} 
diatur dan ditangani adalah perbuatan, tingkah laku, sikap dan/atau ucapan yang dapat merendahkan dan merongrong kewibawaan, martabat, dan kehormatan badan peradilan yang di dunia internasional dikenal dengan contempt of court. UU Kehakiman ini dapat dikatakan merupakan landasar filosofi sekaligus yuridisi atas urgensi keberadaan undang-undang yang mengatur tentang contempt of court.

\section{Peraturan Kode Etik Profesi Penegak Hukum}

Peradilan di dalamnya mengandung makna bukan saja institusi pengadilan sebagai lembaga, namun juga kehormatan dan marwah aparat penegak hukum yang menyelenggarakan sistem peradilan itu sendiri yang meliputi proses pemeriksaan saksi-saksi, pemeriksaan terdakwa, dan pemeriksaan barang bukti. ${ }^{26}$ Dalam konteks peradilan pidana, Barda Nawawi Arief secara eksplisit menyatakan "bahwa sistem peradilan pidana identik dengan sistem kekuasaan kehakiman di bidang hukum pidana yang diimplementasikan dalam empat subsistem, yaitu (1) kekuasaan penyidikan oleh lembaga penyidik; (2) kekuasaan penuntutan oleh lembaga penuntut umum; (3) kekuasaan mengadili/menjatuhkan putusan oleh badan peradilan; dan (4) kekuasaan pelaksanaan hukum pidana oleh aparat pelaksana eksekusi". ${ }^{27}$ Berdasarkan penjelasan di atas, maka penyelenggara sistem peradilan meliputi kepolisian, advokat, kejaksaan, dan kehakiman. Secara personal, ada polisi, advokat, jaksa, dan hakim.

Pada kode etik advokat, antara lain disebutkan bahwa "Dalam perkara perdata yang sedang berjalan, advokat hanya dapat menghubungi hakim apabila bersama-sama dengan advokat pihak lawan, dan apabila ia menyampaikan surat, termasuk surat yang bersifat ad informandum maka hendaknya seketika itu tembusan dari surat tersebut wajib diserahkan atau dikirimkan pula kepada advokat pihak lawan." Pada bagian lain disebutkan,

\footnotetext{
${ }^{26}$ Oly Viana Agustine, Sistem.. Op. Cit., hal 119.

${ }^{27}$ Ibid., hal 5.
} 
"advokat tidak dibenarkan mengajari dan atau mempengaruhi saksi-saksi yang diajukan oleh pihak lawan dalam perkara perdata atau oleh jaksa penuntut umum dalam perkara pidana". ${ }^{28}$ Pelangggaran atas kode etik ini, seorang advokat akan diperiksa dan dijatuhi sanksi etik oleh sebuah Dewan Kehormatan. Dewan Kehormatan ini berwenang memeriksa dan mengadili perkara pelanggaran Kode Etik yang dilakukan oleh Advokat. ${ }^{29}$

Kode etik kepolisian yang disebut Kode Etik Profesi Polri (KEPP) diatur dalam Peraturan Kepala Kepolisian Negara Republik Indonesia nomor 14 tahun 2011 tentang Kode Etik Profesi Kepolisian Negara Republik Indonesia. Dalam KEPP dikenal adanya Etika Kenegaraan; Etika Kelembagaan; Etika Kemasyarakatan; dan Etika Kepribadian. ${ }^{30}$ Pada beberapa ketentuan KEPP ini, diatur norma larangan dan kewajiban etik bagi anggota polri sebagai individu, sebagai pimpinan, maupun sebagai anggota, yang mengharuskan setiap anggota kepolisian berlaku professional dalam menjalankan tugasnya. Misalnya, dalam pasal 14 KEPP diatur bahwa setiap anggota Polri dalam melaksanakan tugas penegakan hukum sebagai penyelidik, penyidik pembantu, dan penyidik dilarang merekayasa isi keterangan dalam berita acara pemeriksaan.

Kode etik profesi jaksa, diatur dalam Peraturan Jaksa Agung Republik Indonesia Nomor Per-014/A/JA/11/2012 tentang Kode Perilaku Jaksa. Kode Perilaku Jaksa atau Perja, di dalamnya mengatur tentang larangan dan kewajiban etik seorang jaksa dalam menjalankan profesinya, dan juga ketentuan jaminan perlindungan hukum bagi jaksa yang menjalankan kode etik tersebut. Salah satu contoh norma etik adalah Pasal 7 ayat (1), bahwa dalam melaksanakan tugas profesinya, seorang jaksa dilarang melakukan

\footnotetext{
${ }^{28}$ Pasal 7 huruf c, d, e, “Kode Etik Advokat. Lihat, Komite Kerja Advokat Indonesia, Kode Etik Advokat Indonesia”, Jakarta, 23 Mei, 2002.

${ }^{29}$ Pasal 10 ay at (1) "Kode Etik Advokat". Lihat, Ibid.

${ }^{30}$ Pasal 4, "Peraturan Kepala Kepolisian Negara Republik Indonesia Nomor 14 tahun 2011 tentang Kode Etik Profesi Kepolisian Republik Indonesia".
} 
permufakatan secara melawan hukum dengan para pihak yang terkait da lam penanganan perkara.

Kode etik dan pedoman perilaku hakim diatur dalam Keputusan Bersama Ketua Mahkamah Agung RI dan Ketua Komisi Yudisial RI nomor 047/KMA/SKB/IV/2009 dan 02/SKB/P/KY/IV/2009 tentang Kode Etik dan Pedoman Perilaku Hakim. Pada bagian pembukaan, dinyatakan secara jelas latar belakang urgensi keberadaan KEPPH ini, bahwa, ${ }^{31}$ "Pengadilan yang mandiri, netral (tidak memihak), kompeten, transparan, akuntabel dan berwibawa, yang mampu menegakkan wibawa hukum, pengayoman hukum, kepastian hukum dan keadilan merupakan conditio sine qua non atau persyaratan mutlak dalam sebuah negara yang berdasarkan hukum. Pengadilan sebagai pilar utama dalam penegakan hukum dan keadilan serta proses pembangunan peradaban bangsa. Tegaknya hukum dan keadilan serta penghormatan terhadap keluhuran nilai kemanusiaan menjadi prasyarat tegaknya martabat dan integritas Negara."

Berdasarkan pembahasan di atas, maka jelas bahwa kehormatan lembaga penegak hukum, hadir dalam wujud paling konkretnya adalah profesionalitas aparat penegak hukum itu sendiri. Sehingga keberadaan kode etik profesi penegak hukum menjadi signifikan keberadaannya dalam rangka menjaga marwah proses penegakan hukum, atau dalam ruang yang sempit lagi marwah peradilan.

\section{Peraturan Tata Tertib Persidangan}

Norma contempt of court juga dapat ditemukan dalam aturan norma tata tertib persidangan dalam rangka memberikan penghormatan dan menjaga marwah peradilan. Misal di Pengadilan Negeri Sleman, diatur

${ }^{31}$ Lihat bagian pembukaan dalam "Keputusan Bersama Ketua Mahkamah Agung RI dan Ketua Komisi Yudisial RI nomor 047/KMA/SKB/IV/2009 dan 02/SKB/P/K Y/IV/2009 tentang Kode Etik dan Pedoman Perilaku Hakim". 
sedemikian rupa terkait tata tertib sidang. Terhadap para pengunjung diberlakukan aturan sebagai berikut: ${ }^{32}$

a. Dilarang berbicara dengan pengunjung yang lain selama sidang berlangsung.

b. Dilarang berbicara memberikan dukungan atau mengajukan keberatan atas keterangan yang diberikan oleh saksi selama persidangan.

c. Dilarang memberikan komentar/saran/tanggapan terhadap sesuatu yang terjadi selama persidangan tanpa ijin Majelis Hakim.

d. Dilarang berbicara keras di luar ruang sidang yang dapat menyebabkan suara masuk ke ruang sidang dan mengganggu jalannya persidangan.

Atas pelanggaran tata tertib di atas, petugas pengadilan dapat meminta atau mengingatkan pihak pelanggar untuk menghentikan pelanggarannya, dan jika masih tidak mengindahkan peringatan, maka petugas pengadilan dapat mengusir keluar secara paksa pelanggar tata tertib dari lingkungan peradilan.

\section{Kitab Undang-Undang Hukum Acara Pidana}

Dalam sebuah sesi wawancara, Wakil Ketua MA, Sunarto, menyebutkan bahwa konten contempt of court sejauh ini dapat diidentifikasi antara lain dalam Pasal 217-218 Kitab Undang-Undang Hukum Acara Pidana (KUHAP). ${ }^{33}$ Pasal 217 KUHAP, Hakim Ketua berfungsi memimpin dan memelihara tata tertib sidang. Pada ayat (2) tegas disebutkan kewajiban bagi setiap orang, bahwa segala hal yang diperintahkan oleh Hakim Ketua Sidang dalam rangka memelihara ketertiban wajib dilaksanakan dengan segera dan cermat.

Pasal 218 KUHAP secara rinci juga disebutkan tentang menjaga sikap hormat kepada pengadilan. “(1) Dalam ruang sidang siapapun wajib

32 http://pn-sleman.go.id/new//link/2015092911230228117560a58763de55.html, diakses pada hari Jumat, 18 Januari 2019, pukul 06.00 WIB.

33 Tiga Hal yang Harus Kita Ketahui soal "Contempt of Court"'," dalam https://nasional.kompas.com/read/2019/08/02/09061931/tiga-hal-y ang-harus-kita-ketahui-soal-contempt-of-c ourt?page=all, diakses pada 3 Agustus 2019. 
menunjukkan sikap hormat kepada pengadilan; (2) Siapa pun yang di sidang pengadilan bersikap tidak sesuai dengan martabat pengadilan dan tidak mentaati tata tertib setelah mendapat peringatan dari hakim ketua sidang, atas perintahnya yang bersangkutan di keluarkan dari ruang sidang. (3) Dalam hal pelanggaran tata tertib sebagaimana dimaksud dalam ayat (2) bersifat suatu tindak pidana, tidak mengurangi kemungkinan dilakukan penuntutan terhadap pelakunya”.

\section{Kitab Undang-Undang Hukum Pidana (KUHP)}

KUHP melalui delik-deliknya yang digolongkan sebagai kejahatan terhadap penyelenggaraan peradilan, dan perbuatan contempt of court oleh kebanyakan pendapat disamakan dengan jenis kejahatan jenis tersebut. Ketiadaan nomenklatur contempt of court dalam KUHP bukanlah berarti undang-undang tersebut tidak mengakui adanya perbuatan contempt of court. Perbedaan sistem hukum menjadikan istilah contempt of court yang dikenal dalam sistem hukum common law tidak dikenal di Indonesia. Namun ada padanan istilah lain dengan konotasi yang sebenarnya sama, yakni kejahatan terhadap peradilan. ${ }^{34}$

Beberapa ketentuan pasal-pasal dalam KUHP berikut dapat digolongkan sebagai norma contempt of court, meliputi:

a. Pasal 207; tentang penghinaan kepada penguasa atau badan umum yang termasuk di dalamnya peradilan dan penyelenggara peradilan.

b. Pasal 210 dan Pasal 420; tentang pemberian suap kepada hakim maupun advokat untuk mempengaruhi pertimbangan dan keputusan hukum, diancam kepada pemberi suap, maupun penerima suap.

c. Pasal 217; mengenai perbuatan yang menimbulkan kegaduhan dalam sebuah peradilan.

d. Pasal 221, Pasal 222, Pasal 223 dan Pasal 417; pada pokoknya mengatur tentang perbuatan menghalangi jalannya peradilan

${ }^{34}$ Andi Hamzah, "Kejahatan Terhadap Penyelenggaraan Peradilan (Contempt of Court)", PT. Alumni, 2017, Bandung, hal 12. 
(obstructing justice), mulai dari menyembunyikan buronan, menghalangi Tindakan forensik, melepas atau memberi pertolongan orang yang sedang dalam tahanan, dan perusakan alat bukti kejahatan.

e. Pasal 224, Pasal 225, Pasal 226, dan Pasal 227; pada pokoknya mengatur perbuatan ketidakpatuhan terhadap perintah atau putusan hakim yang dominan, perbuatan demikian sebagaimana yang dikenal dalam salah satu bentuk contempt of court dalam teori, yaitu disobeying a court order.

f. Pasal 231 dan Pasal 232; pada pokoknya mengatur perbuatan terkait barang bukti dan barang sitaan.

\section{Peraturan Pidana di Luar KUHP}

Sebagaimana ketentuan contempt of court dalam KUHP, beberapa pengaturan contempt of court dalam ketentuan undang-undang di luar KUHP juga tidak menyebutkan secara eksplisit dalam pasal-pasalnya mengenai pelanggaran contempt of court. Penggunaan istilah contempt of court hanya diberlakukan secara praktikal dalam sidang pengadilan, selebihnya beberapa norma mengenai contempt of court di luar ketentuan KUHP ini juga dinilai masih menuai banyak pro dan kontra terkait kedudukannya sebagai ketentuan contempt of court. Di luar dari berbagai persoalan mengenai penegakan hukum norma contempt of court dalam beberapa undang-undang, pengaturan contempt of court dalam beberapa undang-undang khusus dinilai sangat membantu dalam menjaga integritas dan martabat peradilan, selain juga dalam penegakan hukum terhadap kasus-kasus khusus dengan potensi pelanggaran contempt of court yang juga lebih dari pada kasus-kasus konvensional biasanya. Beberapa delik contempt of court dalam undang-undang di luar KUHP setidaknya dapat dilihat dalam 5 (lima) ketentuan peraturan perundang-undangan, meliputi:

a. UU Tipikor (Undang-Undang Nomor Nomor 31 Tahun 1999 jo. Undang-Undang Nomor 20 Tahun 2001 tentang Pemberantasan 
Tindak Pidana Korupsi): Pasal 21, Pasal 22 jo. Pasal 29, Pasal 22 jo. Pasal 35, dan Pasal 22 jo. Pasal 36.

b. UU TTPO (Undang-Undang Nomor 21 Tahun 2007 tentang Pemberantasan Tindak Pidana Perdagangan Orang): Pasal 20, Pasal 21, Pasal 22 dan Pasal 23.

c. UU Narkotika (Undang-Undang Nomor 35 Tahun 2009 tentang Narkotika): Pasal 138 dan Pasal 143.

d. UU TPPU (Undang-Undang Nomor 8 Tahun 2010 tentang Pencegahan dan Pemberantasan Tindak Pidana Pencucian Uang): Pasal 87.

e. UU Terorisme (Peraturan Pemerintah Pengganti Undang-Undang Nomor 1 Tahun 2002 tentang Pemberantasan Tindak Pidana Terorisme yang telah ditetapkan sebagai Undang-Undang Nomor 15 Tahun 2003 sebagaimana telah dirubah menjadi Undang-Undang Nomor 5 Tahun 2018): Pasal 20, Pasal 21 dan Pasal 22.

\section{Rancangan Kitab Undang-Undang Hukum Pidana}

Ketentuan contempt of court selain diatur dalam beberapa norma peraturan yang eksis dan berlaku, dalam RKUHP ternyata juga ada. Hal ini dikarena RKUHP merupakan reinkarnasi dari KUHP yang saat ini ada, sehingga ada beberapa pasal yang diubah, ditambah, atau dihapuskan. Ada beberapa peraturan di dalam KUHP saat ini masih dipertahankan dalam RKUHP yang terbaru. Dalam RKUHP semakin diperjelas kedudukan berbagai pasal yang semula berada di berbagai lokasi dalam KUHP menjadi satu bab khusus yaitu Bab Tindak Pidana Terhadap Proses Peradilan, mulai dari Pasal 281 sampai dengan Pasal 303. Ini artinya ada paling tidak 22 Pasal dalam RKUHP yang mengatur tentang tindak pidana terkait contempt of court. ${ }^{35}$

\footnotetext{
${ }^{35}$ Lihat RKUHP versi akhir tanggal 15 September 2019.
} 
Berdasarkan kajian di atas, peraturan terkait dengan contempt of court di Indonesia dapat digambarkan sebagai berikut:

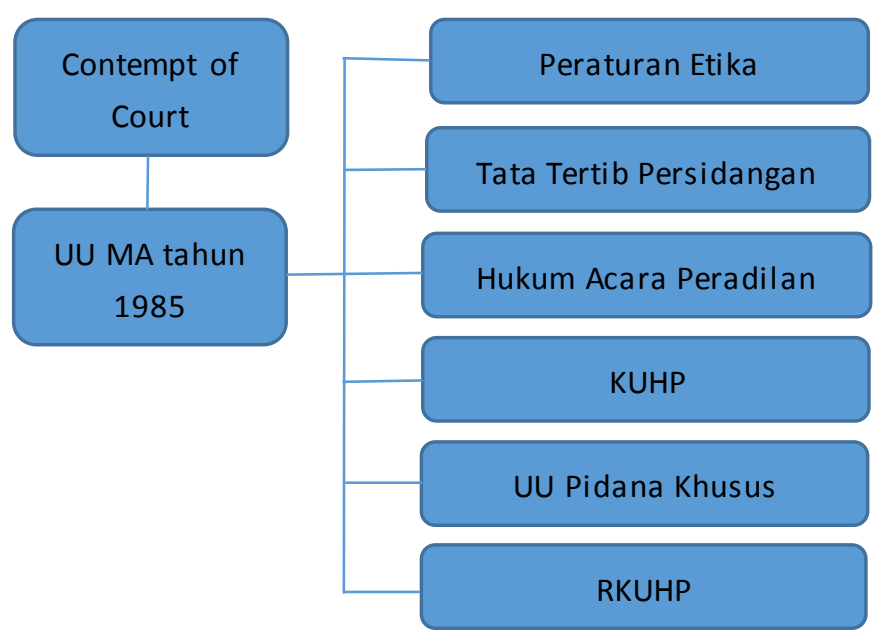

Bagan 1: Sekema Peraturan Terkait Contempt of Court di Indonesia

\section{Peta dan Ruang Lingkup Contempt of Court}

Indonesia dengan konsep negara hukumnya, ${ }^{36}$ kekuasaan tertinggi ada dan ditempatkan pada hukum (supremacy of law). ${ }^{37}$ Termasuk di dalamnya adalah menjadikan hukum sebagai sumber utama dalam menanggulangi jenis pelanggaran tersebut. Dianutnya konsep contempt of court sebagai produk sistem hukum common law pada negara civil law seperti Indonesia tentunya memberikan dimensi baru dalam memahami kedudukan contempt of court tersebut. Adanya perbedaan sistem hukum yang dimiliki, Indonesia sebagai negara penganut sistem hukum eropa kontinental (civil law) ${ }^{38}$ menempatkan contempt of court sebagai

${ }^{36}$ Pasal 3 UUD NRI 1945.

37 Teguh Prasetyo, "Rule of Law dalam Dimensi Negara Hukum Indonesia”, Refleksi Hukum, Fakultas Hukum UKSW, 2010, Slatiga, hal 133. URI: http://repository.uksw.edu/handle/123456789/3221

${ }^{38}$ Choky R. Ramadhan, "Konvergensi Civil Law dan Common Law di Indonesia Dalam Penemuan

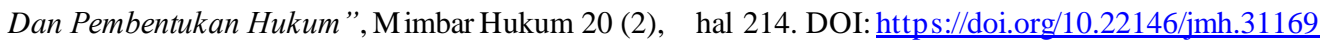


pelanggaran hukum yang pengaturannya diatur berdasarkan peraturan perundang-undangan tertulis. ${ }^{39}$

Meskipun telah diatur dalam berbagai macam aturan tertulis, tidak dapat diolak lagi bahwa sampai saat ini istilah contempt of court di Indonesia masih menuai berbagai problematika keterbatasan norma dan implementasinya. ${ }^{40}$ Terlepas dari persoalan tersebut, memahami ruang lingkup perbuatan yang dapat digolongkan ke dalam perbuatan contempt of court merupakan hal yang penting untuk dapat mengimplementasikan sebagaimana mestinya. Setidaknya terdapat tiga kelompok ruang lingkup perbuatan contempt of court dalam sistem peraturan perundang-undangan di Indonesia yang terdiri dari; pertama, dimensi perbuatan contempt of court sebagai pelanggaran etik; kedua, perbuatan contempt of court sebagai domain pelanggaran tata tertib; dan ketiga, perbuatan contempt of court sebagai suatu tindak pidana. Secara skematis dapat digambarkan sebagai berikut:

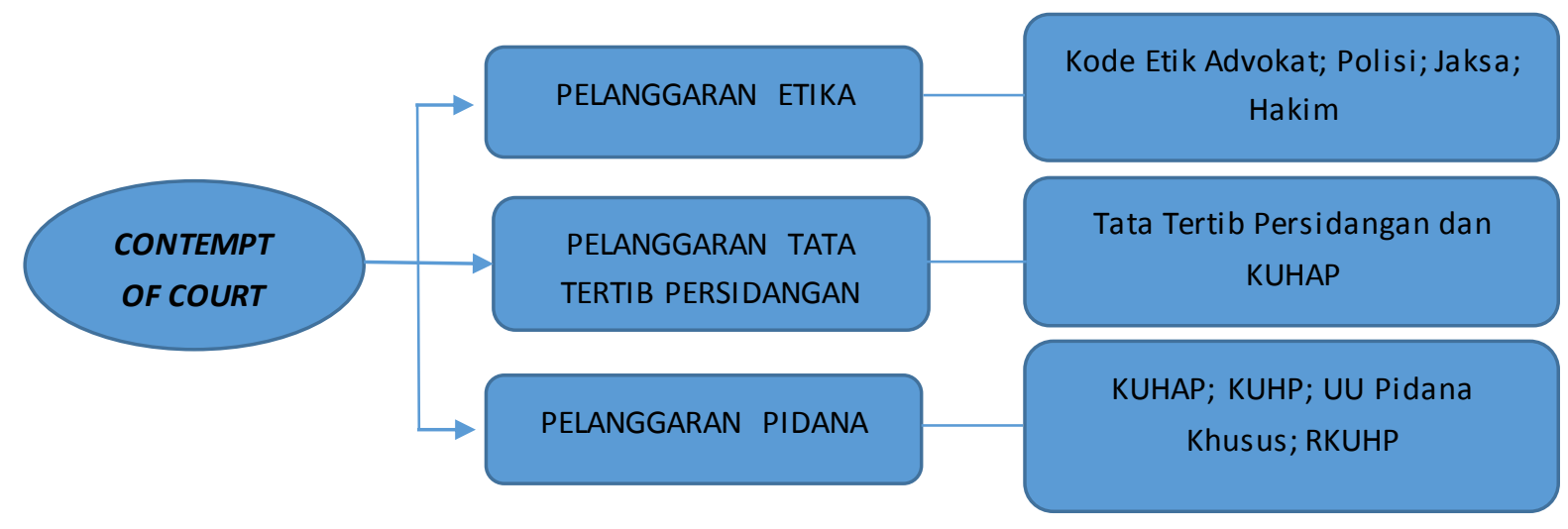

Bagan 2. Skema Ruang Lingkup Contempt of Court

\footnotetext{
${ }^{39}$ Hasbullah F. Sjawie, "Sekelumit Catatan Mengenai Tindak Pidana "Contempt of Court" di Indonesia”, Jurnal Hukum dan Pembangunan 24 (4) 1994, hal 328.

DOI: http://dx.doi.org/10.21143/jhp.vol24.no4.452

40 Ibid., hal 327.
} 
Ragam pelanggaran yang masuk dalam kategori contempt of court, menjadikan peta penyelesaiannya juga beragam. Pelanggaran atas kode etik, pada masing-masing satuan profesi penegak hukum, diselesaikan melalui komisi etik. Bentuk sanksinya juga berupa sanksi etik. Sanksi ini bersifat evaluatif dan disiplin. Lembaga penegakan bersifat internal, kecuali untuk profesi hakim, karena sudah ada Komisi Yudisial yang mengawasi perilaku hakim. Karena sifatnya internal, seringkali hasil keputusan dinilai kurang memuaskan publik.

Contempt of court dalam bentuk pelanggaran atas tata tertib, diselesaikan secara langsung oleh otoritas yang berwenang. Pihak yang berwenang bisa petugas peradilan maupun hakim atau manajemen pengadilan secara langsung. Sanksi yang diberikan, dapat berupa pemberian peringatan sampai dengan tindakan tertentu seperti pengusiran, atau larangan memasuki ruang persidangan. Sifat pelanggaran ini bersifat pelanggaran atas tata tertib, sehingga bentuk sanksinyapun bersifat tindakan untuk memastikan ketertiban terjaga.

Contempt of court dalam bentuk pelanggaran pidana, diselesaikan secara hukum. Ranah pelanggaran ini dipandang sebagai pelanggaran yang paling serius. Mekanisme secara hukum adalah mekanisme yang paling rigid, yang tidak jarang dikeluhkan oleh para pengak hukum. Hal ini tidak lepas dari permasalahan belum adanya hukum acara yang pasti untuk kasus contempt of court yang masuk ranah pidana. Selain itu, keberadaan norma yang saat ini ada, sifatnya sangat subjektif. Misalnya, dalam praktek, ukuran perbuatan menghambat, merendahkan, dan mengalangi proses peradilan sangat ditentukan oleh sikap pihak aparat penegak hukum terhadap perbuatan yang dilakukan. Perusakan sarana umum yang kebetulan adalah gedung peradilan dapat dipandang sebagai contempt of court. Norma yang ada saat ini, baik dalam KUHAP, KUHP, maupun UU pidana khusus, bersifat terbuka. Unsur subjektif pelaku, bahwa dia bermaksud merongrong kewibawaan atau menghalangi proses peradilan perlu dipertegas, sehingga sifat kejahatan terhadap peradilan ini, benar-benar khusus diarahkan kepada 
peradilan, baik aktor penegak hukumnya, prosesnya, maupun kehormatannya.

\section{PENUTUP}

Berdasarkan kajian yang telah dilakukan, maka dapat dirumuskan kesimpulan sebagai berikut: pertama, bahwa contempt of court di Indonesia belum diatur secara terpadu dalam satu peraturan perundang-undangan sebagaimana diamanatkan dalam UU No. 14 tahun 1985 tentang Mahkamah Agung. Sementara pengaturan tentang CoC dapat ditemukan dalam beberapa norma yaitu (1) Peraturan Kode Etik Penegak Hukum; (2) Peraturan Tata Tertib Persidangan; (3) Kitab Undang-Undang Hukum Acara Pidana; (4) Kitab Undang-Undang Hukum Pidana; (5) Peraturan Pidana di Luar KUHP; (6) Rancangan Kitab Undang-Undang Hukum Pidana. Kedua, ruang lingkup contempt of court sebagai sebuah perbuatan yang dilarang, ternyata dapat diidentifikasi berdasarkan peraturan yang mengatur dan sifat larangannya menjadi beberapa kategori. (1) Contempt of court sebagai pelanggaran etik. Penegakan atas pelanggaran ini dilakukan oleh dewan etik masing-masing profesi penegak hukum. (2) Contempt of court sebagai pelanggaran tata tertib. Pelanggaran atas ini dapat dikenakan teguran langsung atau sampai pada tindakan pengusiran dan pelarangan memasuki ruang sidang atau lingkungan peradilan. (3) Contempt of court sebagai pelanggaran pidana dengan mekanisme penyelesaian melalui sistem peradilan pidana. Berdasarkan kajian yang dilakukan, beberapa saran dapat disampaikan agar dapat menjadi pertimbangan perbaikan pengaturan contempt of court ke depan di Indonesia. (1) Perlu diadakan kesepakatan penggunaan istilah yang baku dalam bahasa Indonesia untuk istilah contempt of court, mengingat istilah ini berasal dari negeri seberang; (2) Perlu dikaji lebih lanjut ruang lingkup perbuatan dan kemungkinan norma aturannya, sehingga secara politik legislasinya akan jelas, apakah dibuatkan undang-undang tersendiri sebagaimana amanat UU No. 14 tahun 1985 tentang Mahkamah Agung, ataukah cukup dimasukkan dalam satu bab khusus dalam rancangan KUHP ke depan. 


\section{DAFTAR PUSTAKA}

\section{Buku}

Andi Hamzah, "Kejahatan terhadap Penyelenggaraan Peradilan (Contempt of Court)”, PT. Alumni, 2017, Bandung.

Henry Black Campbell, "Black's Law Dictionary”, Abridged Fifth Edition, ST. Paul. MINN. West Publishing Co., 1983.

Lilik Mulyadi dan Budi Suharyanto, "Contempt of Court di Indonesia”, Alumni, 2016, Bandung.

Oly Viana Agustine, "Sistem Peradilan Pidana: Suatu Pembaharuan”, Rajawali Pers, 2019, Depok.

Saifuddin Azwar, “Metode Penelitian”, Ctk. Kedua, Pustaka Pelajar, 1999, Yogyakarta.

Soerjono Soekanto, "Pengantar Penelitian Hukum”, Cet. 3, Penerbit Universitas Indonesia, 2012, Jakarta.

Soetand yo Wignyosoebroto, "Hukum Konsep dan Metode”, Setara Press, 2013, Malang.

Sulistyo wati Irianto \& Shidarta (ed), "Metode Penelitian Hukum; Konstalasi dan Refleksi”, Yayasan Obor Indonesia, 2009, Jakarta.

Wahyu Wagiman dkk., "Contempt of Court dalam Rancangan KUHP”, Position Paper Advokasi RUU KUHP Seri\#2, Tim Elsam, 2005, Jakarta.

Wildan Suyuthi Mustofa, "Kode Etik Hakim”, Edisi Kedua, Kencana, 2013, Jakarta.

\section{Jurnal}

Amirudin, "Delik Penghinaan Terhadap Pengadilan (Contempt of Court) dalam Perkara Pidana di Indonesia”, Jurnal Penelitian Hukum Legalitas 9 (2), 2016.

DOI: 10.31479/jphl.v9i2.107

Artaji dkk, "Eksistensi Pranata Contempt of Court dalam Peradilan di Indonesia", Jurnal Pengabdian Kepada Masyarakat 2 (8), 2018.

DOI: http://jurnal.unpad.ac.id/pkm/article/view/20309

Choky R. Ramadhan, "Konvergensi Civil Law dan Common Law di Indonesia dalam Penemuan dan Pembentukan Hukum”, Mimbar Hukum 30 (2), 2018. DOI: https:/doi.org/10.22146/jmh.31169

Hasbullah F. Sjawie, "Sekelumit Catatan Mengenai Tindak Pidana "Contempt of Court" di Indonesia", Jurnal Hukum dan Pembangunan 24 (4), 1994.

DOI: http://dx.doi.org/10.21143/ihp. vol24.no4.452

Rhivent Marchel Michael Samatara, "Tindak Pidana Terhadap Lembaga Peradilan (Contempt of Court) Menurut Hukum Positif Indonesia”, Lex Privatum 5 (9) 2017. Manado.

DOI: https://ejournal.unsrat.ac.id/index.php/lexprivatum/article/view/18351

Ruby Hadiarti Johny, "Contempt Of Court (Kajian tentang Ide Dasar dan Implementasinya dalam Hukum Pidana)”, Jurnal Dinamika Hukum 9 (2), 2009. 
DOI: $10.20884 / 1 . j \mathrm{dh} .2009 .9 \cdot 2.221$

Sutanto Nugroho dkk., "Pengaturan Tindak Pidana Contempt of Court Berdasarkan Sistem Hukum Pidana Indonesia”, Diponegoro Law Journal 6 (2), 2017.

Teguh Prasetyo, "Rule of Law dalam Dimensi Negara Hukum Indonesia”, Refleksi Hukum, 2010.

\section{Peraturan Perundang-Undangan}

\section{UUD NRI 1945}

Kitab Undang Undang Hukum Acara Pidana

Kitab Undang Undang Hukum Pidana

Undang-Undang Nomor Nomor 31 Tahun 1999 jo. Undang-Undang Nomor 20 Tahun 2001 tentang Pemberantasan Tindak Pidana Korupsi.

Undang-Undang Nomor 21 Tahun 2007 tentang Pemberantasan Tindak Pidana Perdagangan Orang.

Undang-Undang Nomor 35 Tahun 2009 tentang Narkotika.

Undang-Undang Nomor 8 Tahun 2010 tentang Pencegahan dan Pemberantasan Tindak Pidana Pencucian Uang.

Peraturan Pemerintah Pengganti Undang-Undang Nomor 1 Tahun 2002 tentang Pemberantasan Tindak Pidana Terorisme yang telah ditetapkan sebagai Undang-Undang Nomor 15 Tahun 2003 sebagaimana telah dirubah menjadi Undang-Undang Nomor 5 Tahun 2018

Kode Etik Advokat. Lihat, Komite Kerja Advokat Indonesia, Kode Etik Advokat Indonesia, Jakarta, 23 Mei, 2002.

Peraturan Kepala Kepolisian Negara Republik Indonesia Nomor 14 tahun 2011 tentang Kode Etik Profesi Kepolisian Republik Indonesia.

Keputusan Bersama Ketua Mahkamah Agung RI dan Ketua Komisi Yudisial RI nomor 047/KMA/SKB/IV/2009 dan 02/SKB/P/KY/IV/2009 tentang Kode Etik dan Pedoman Perilaku Hakim.

RKUHP tanggal 15 September 2019.

\section{Lain-Lain}

Bahan Pelatihan ToT Program Klinik Etik dan Hukum, yang diselenggarakan oleh Komisi Yudisial pada tanggal 12-15 Maret 2018, di Bandung

\section{Internet}

www.ma.go.id. http://pn-sleman.go.id/new//link/2015092911230228117560a58763de55.html https://nasional.kompas.com/read/2019/08/02/09061931/tiga-hal-yang-harus-kitaketahui-soal-contempt-of-court?page $=$ all 